\title{
A TEORIA TRIDIMENSIONAL DO DIREITO
}

PROF. WILSON ALVES CHAGAS

Reunir os elementos contrastantes da experiência jurídica. Aglutinar fato, valor e norma, mostrar como o Direito reflete a própria imagem em cada um dêles, e contudo sòmente se encontra a si mesmo - ou pode ser realizado - em conjunto, e na concreção dinâmica daí resultante. Eis a idéia-motora que inspirou a Teoria Tridimensional do Direito de Miguel Reale.

Implicação, portanto, de fato social, regra jurídica e valoracão ética da conduta. Esses três fatôres ou essas três dimensões da realidade jurídica se implicam e supõem mùtuamente. São complementares. De todos êles resulta o Direito como tal. Concreto, dinâmico, abrangente de tôda a conduta humana, que positivismo ou sociologismo jurídico, normativismo e jusnaturalismo, enquanto concepções conflitantes do Direito, se harmonizam, dialèticamente, no tridimensionalismo.

É ao nível da "experiência jurídica", como $_{0}$ se vê, que Reale fundamenta, de fato, o seu tridimensionalismo. Com efeito, é nesse nível 1) que os três elementos ou as três dimensões do fato, do valor e da norma se apresentam e se consociam, num processo contínuo de interação dialética, "de implicação e polaridade"; 2) é ainda nesse plano que funciona a concreção postulada por Reale para o sincretismo da sua teoria. Essa visão integral do Direito que o filósofo brasileiro nos quer dar se passa num plano, digamos, de "mostração" da sua estrutura. Assim se apresenta o Direito ou êle assim se compõe - quando o vemos atuando, concretamente, dentro de situações sociais e históricas dadas. Mas qual o significado dessa mostração tripartida-unitária, dessa concreção de fato, valor e norma na funcionalidade da experiência jurídica? Qual, noutras palavras, a "filosofia" dessa tridimensionalidade? 
A impressão que se tem é que não é atravessado o limiar da compreensão do problema, e que algo está faltando para isso. Precisamente do ponto de vista filosófico. A Teoria Tridimensional de Miguel Reale corresponde a uma descrição matizada do fenômeno jurídico. Seria preciso interpretar os dados em que se baseia, para outras conclusões. Mas isto nos levaria além do tridimensionalismo.

Mas, tornemos a perguntar: qual o alcance da "fórmula Reale" (para utilizarmos a expressão de Josef Kunz, no seu estudo "sôbre a problemática da Filosofia do Direito nos meados do século 20")? Com efeito, que significa afirmar que o Direito tem uma estrutura tridimensional? - Significa o reconhecimento das zonas ou dimensões que o integram, como camadas não apenas superpostas, mas que se interpenetram - pois é na sua própria "estrutura" que se dá a tríplice perspectiva, a tríplice aliança de seus componentes.

Assenta Reale que "fato, valor e norma estão sempre presentes e correlacionados em qualquer expressão da vida jurídica, seja ela estudada pelo filósofo ou o sociólogo do Direito, ou pelo jurista como tal" (Teoria Tridimensional do Direito, Ed. Saraiva, São Paulo, 1968, p.73). E ainda, que essa correlação "é de natureza funcional e dialética, dada a implicação-polaridade existente entre fato e valor, de cuja tensão resulta o momento normativo" ( $p$. 74). Mas o que resulta de tal visão integrativa de fato, valor e norma no campo do Direito? Ter-se-á, dessa forma, compreendido melhor o fenômeno jurídico?

Não cremos. Dessa forma se enunciam "dimensões" ou fatôres que se encontram no Direito, mas que não o esclarecem suficientemente. Trata-se de um esquema descritivo, já dissemos, que cumpriria desenvolver, aprofundar e até superar... Um simples esquema metodológico. Reale pretende, ao contrário, que se trata de três elementos essenciais, estruturais, da experiência jurí dica. Vejamos em que sentido seria possivel reformular a Teoria Tridimensional do Direito, a partir de tal esquema.

$\mathrm{O}$ valor, acionado pelo fato, é, com êle, e através dêle, convertido em norma. Que valor é êsse, assim "acionado" pelo fato? $\mathrm{E} o$ que é êsse fato, que assim "aciona" o valor?

O fato é o acontecimento histórico. E um fato já valorado, ou que já contém o valor, embora a um nível não pròpriamente valorativo, quero dizer, que não dispensa, antes exige a sua reelaboração pelo homem. Constitui, neste sentido, um "desafio" à liberdade humana, um agente desencadeante de novos fatos, de novos acontecimentos históricos. Então: o valor "acionado" pelo fato quer dizer o valor que é "investido", desafiado e pôsto em movimento pelo que "acontece": é o valor pôsto em cena, obriga- do a jogar-se, com o poder de suas decisões e opções, no plano concreto da História. Neste sentido se pode dizer que o valor é constantemente "convocado" pelos fatos, é constantemente reativado para que assuma, aqui e agora, a sua tarefa e a sua missão histórica.

E o homem que, sob o impacto dos fatos, e compreendendo o seu "processo", lhes imprime direção, dá sentido à História. E essa a função do valor. Mas êsse valor nada vale - ou não iem esteio - se não é "acionado" pelos fatos, na forma acima indicada. A "objetividade" vem de fora: também a "fôrça" ou o impulso" para a atividade valorativa central. Pelo valor é constantemente reelaborado, assim, o que já tem espessura histórica e portanto já é resultado, não de uma, mas de múltiplas valorações. Daí a "concreção" própria ao fato social, ao acontecimento histórico em geral. Uma concreção que resulta de interações dialéticas, de sínteses sucessivas, mas comportando, sempre, novas valorações, ou novas maneiras de serem assumidas e transformadas pelo agir humano, ou pela liberdade.

Qualquer outra posição em face do problema não leva em conta a objetividade histórica, real, do fato. Por outro lado - e por isso mesmo - lhe escapa o "ato", os diversos "atos" que se encontram sob os "fatos", ou seja, lhe escapa o processo mesmo de "fatualização" ou de concreção histórico-dialética de que brota, sempre, cada fato, cada acontecimento. E é essa reformulação dos elementos (combinados) da tridimensionalidade que deve ser aplicada ao setor normativo do Direito para aproveilar o que há de positivo na "fórmula Reale". Eis a sugestão que entrego aos estudiosos. 